\title{
LATE RESULTS OF GOLD TREATMENT IN RHEUMATOID ARTHRITIS
}

\author{
BY \\ N. EGELIUS, N. G. HÄVERMARK, and G. NYSTRÖM \\ From the Department for Medical and Rheumatic Diseases, Södersjukhuset \\ (South Hospital), Stockholm. (Director: Eric Jonsson, M.D.) \\ (RECEIVED FOR PUBLICATION JULY 2, 1951)
}

Gold treatment has always been a matter of debate; this is partly owing to the difficulties in judging the results, and partly owing to toxic secondary effects. The tendency of rheumatoid arthritis to spontaneous remissions and progressions has not been sufficiently taken into account. In addition, the various case histories are not comparable, since they fail to give elementary information concerning the age-distribution, sex, duration of history, etc. Several authors define the terms "healed, improved, unchanged, and deteriorated" more or less subjectively. Steinbrocker and Blazer (1946) proposed giving points according to the clinical findings to obtain a more objective conception of the effect of this therapy. Generally, most of the published material lacks control groups for the comparison of gold treatment on the one hand, and, e.g., physical treatment only, on the other.

Most authors give only the primary results of treatment, the number of improved cases varying between 50 and 95 per cent. Such a high percentage of improved cases as 95 per cent. is, apparently, due to the inclusion of the mild cases with uncertain diagnosis. As to the late results of this therapy, the figures are much less encouraging. Thus, Ragan and Tyson (1946) showed that in a series of 142 patients, 75 per cent. relapsed in the course of 3 years. Kling, Vento, and Sashin (1949) found that 17 per cent. relapsed in a series of 455 patients after one year, 57 per cent. after 5 years, and 75 per cent. after 10 years.

As stated above, most of the reports lack control groups. Nevertheless, some investigations deal with such groups. Ellman, Lawrence, and Thorold (1940) and Fraser (1945) found that after one year of observation the cases treated with gold showed better results than those not so treated. Secher (1946), after a control examination held 5 to 13 years later on 231 cases of rheumatoid arthritis treated with sanocrysin, showed that 60 to 70 per cent. had improved. Snorrason (1950), partly on the same number of cases, demonstrated an improvement in 80 per cent. after 4 years' follow-up. In a control group given only physical therapy, he obtained only a 50 per cent. improvement. Short, Beckman, and Bauer (1946) declared gold treatment to be of no definite value, but their experience of it was limited to 47 patients. Waine, Baker, and Mettier (1947) published a control examination of 120 patients, 62 of whom had been treated physically and 58 with gold, with doses exceeding $0.5 \mathrm{~g}$. per patient. The cases were followed up for an average of 2.9 years and the percentage of those free from symptoms, or markedly 
improved, was 56.9 for those treated with gold and $29 \cdot 1$ for those treated only physically.

\section{Present Investigation}

In the period from the summer of 1949 to May, 1950, 210 cases of rheumatoid arthritis, treated at the Åsö Hospital and Södersjukhuset in the years 1934 to 1945, were subjected to follow-up examination. All those who had received less than $0.8 \mathrm{~g}$. gold at the first treatment were excluded. Below, the composition of the material and the results of the treatment are set down in tabular form.

TABLE I

PRIMARY MATERIAL

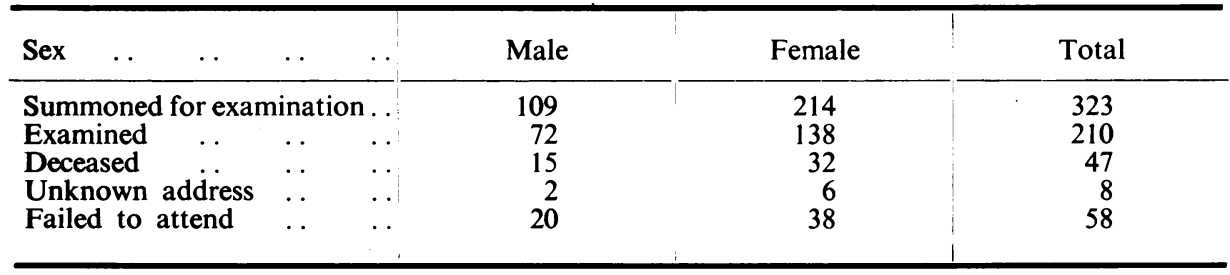

Table I shows that 323 patients were asked by letter to submit to a follow-up examination, and that 210 were examined. This reduction by 113 cases was due to the fact that 47 had died and 66 did not attend for other reasons. The investigation involved sending a questionnaire to the 323 patients constituting the primary material. The following questions were to be answered:

Have you still any trouble in the joints and, if so, will you state the degree of severity?

Have you received any subsequent treatment?

Have you received gold treatment again and, if so, with what result ?

Are you willing to attend a control examination ?

The patients who attended were all subjected to a control examination. Besides the usual somatic examination including joint status, the sedimentation rate was noted, and the blood tested. On the basis of previous records and examination findings filed in our card index, the different patients were classified as shown in Table II.

TABLE II

RESULTS AFTER 5 YEARS OR MORE, BY SEX

\begin{tabular}{|c|c|c|c|c|c|}
\hline \multirow{2}{*}{ Class } & & \multicolumn{2}{|c|}{ Male } & \multicolumn{2}{|c|}{ Female } \\
\hline & & No. & $\%$ & No. & $\%$ \\
\hline $\begin{array}{l}\text { No symptoms .. } \\
\text { Improved }\end{array}$ & $\begin{array}{ll}\ldots & . \\
\cdots & . \\
\cdots & . \\
\ldots & .\end{array}$ & $\begin{array}{l}20 \\
22 \\
11 \\
17\end{array}$ & $\begin{array}{l}28 \\
31 \\
15 \\
26\end{array}$ & $\begin{array}{l}12 \\
42 \\
23 \\
61\end{array}$ & $\begin{array}{l}9 \\
30 \\
17 \\
44\end{array}$ \\
\hline
\end{tabular}

Table II shows the results of treatment after 5 years or more. The material was divided by sex, and a marked difference was found between the sexes as regards 
the results of this treatment. On the basis of the total material, the symptom-free group-which was, moreover, the only one with a preponderance of malesshowed that 28 per cent. males and 9 per cent. females were free from symptoms. The next two groups " improved" and " unchanged " display no great variation between the sexes. Only 26 per cent. of the total number of males were found to have deteriorated, whereas the corresponding figure for females was as high as $\mathbf{4 4}$ per cent. These figures are in fair agreement with the general conception that rheumatoid arthritis affects the female sex the most severely.

TABLE III

INITIAL IMPROVEMENT (\%)

\begin{tabular}{c|c|c}
\hline Male & Female & Total \\
\hline 75 & 80 & 78 \\
\hline
\end{tabular}

Table III shows that quite different figures were obtained concerning the immediate effects of the initial gold treatment. These figures clearly demonstrate that it is impossible to arrive at any judgment of the long-term prognosis merely by reference to the initial effects.

TABLE IV

RESULTS OF TREATMENT BY TIME SINCE ONSET (\%)

\begin{tabular}{c|c|c|c|c}
\hline No. of Years & Symptom-Free & Improved & Unchanged & Deteriorated \\
\hline$<1$ & 56 & 37 & 44 & 26 \\
1 & 22 & 14 & 15 & 21 \\
$2-5$ & 13 & 25 & 32 & 38 \\
$>5$ & 9 & 24 & 9 & 15 \\
\hline
\end{tabular}

Table IV shows, in our opinion, an important principle for gold treatment. It has been ascertained by means of animal experiments that an early administration of gold treatment has a more favourable effect than that obtained if the treatment is started at a later stage of the disease. In the course of years, we have arrived at the same conclusion, and our investigation points in the same direction. Table IV illustrates how the late effect is influenced by the lapse of time between the onset of the disease and the beginning of the gold treatment. It was found that in the symptom-free group as many as 56 per cent. were treated with gold within a year of the onset. In the other groups the results in cases treated with gold before the termination of one year were 37 per cent. improved, 44 unchanged, and 26 deteriorated. The corresponding figures in the various groups of those treated with gold after the elapse of one year do not show the same preponderance in the symptom-free group, and this also applies to the remaining cases treated with gold 
at a later stage. Though the material is limited, in comparing the groups of symptom-free and deteriorated cases, the figures of 56 and 26 per cent. may be said to be significant.

In the different groups of results, the length of time elapsing between the first and second gold treatment was also investigated. It was found that in the more successful cases the second gold treatment had been given a shorter time after the first treatment than in the less successful cases.

Obviously, against these figures and the conclusions drawn from them, the objection may be raised that the patients who are now free from symptoms were of the mild type to begin with, and that their disease would probably have been healed without treatment. In a study of records made at the time of the first gold treatment, based on articular findings, sedimentation rate, serologic titres, etc., the cases were classified as mild, medium-severe, and severe. This classification was not made according to Steinbrocker (1946), but should at any rate give some idea of the material.

Considering the whole series of patients on the basis of this distribution in regard to severity, we did not find that the relation between mild, medium-severe, and severe cases varied sufficiently in the different groups to have influenced the early effects of the gold or the late results.

The different sexes have already been demonstrated as manifesting a different prognosis. Another fact of interest is the age of the patient at the onset of disease. In an analysis of the material, a comparison between the more and less successful from a therapeutic point of view showed that the former had more often fallen ill at a younger age. Using the division into groups of "free from symptoms ", " improved", " unchanged ", and "deteriorated", it will be found that 41 per cent. of the patients who were free from symptoms at the follow-up examination had fallen ill before the age of 30 . The corresponding figures for the groups " improved", " unchanged ", and "deteriorated", were 27, 26.5, and 14 per cent. Similar figures are obtained when 40 years is set as the upper limit. 66 per cent. of the cases free from symptoms fell ill before that age, and in the groups " improved", " unchanged", and "deteriorated ", the corresponding figures are 48, 44, and 38 per cent. Although the differences are insignificant and the cases not numerous, the figures obtained indicate that the earlier onset of the disease involves a somewhat more favourable prognosis.

Yet another factor which might be supposed to influence the course of the disease is the type of attack. Egelius, Hävermark, and Jonsson (1948) published an investigation of early symptoms in rheumatoid arthritis in which the classic onset (viz. stealthy beginning, slowly progressive course, no fever, and symmetric joint symptoms starting in the small joints and progressing centripetally) was demonstrated as being not nearly so common as had been assumed. Compared with more acute or atypical forms of attack, the classic type described above would rather have been expected to prove less favourable as regards the prognosis. The present material has been studied from this particular point of view without yielding any evidence of this. 
From our present endocrinological standpoint, ACTH and cortisone cannot as yet be relied upon to offer any really conclusive cure, and gold treatment must still be considered as the best, though by no means an ideal, procedure. If gold must be used, it is apparently desirable to start the treatment at an early stage; the first course of treatment should be followed, after a short period, preferably 2,3 , or 4 months as stated above, by a fresh course of treatment, or else after the first treatment a maintenance dose should be administered. It has been observed that the gold is all excreted in up to 7-12 months from the discontinuation of the therapy. It would seem important, therefore, to maintain a certain threshold value of the gold in the tissues so as to prevent the disease from breaking out again. The action of gold is unknown. Various theories have been advanced regarding a bacteriostatic action, enzyme inhibition, etc. It is possible that the effect of the gold is an action on the pituitary and adrenal cortex. Attempts have been made to combine gold treatment with ACTH or cortisone administration in order to obtain a better and more protracted effect. Hitherto, however, our experience of this combined therapy has not been encouraging.

As a practical outcome of the present investigation, the initial course of gold treatment is now followed on a larger scale at the Rheumatic Dispensary of Södersjukhuset (South Hospital) by administering small maintenance doses every other, or every third, week ad modum Freyberg (1942).

\section{Summary}

Follow-up examinations were made of 210 rheumatoid arthritis patients (two-thirds of whom were females), 5 to 15 years after gold treatment. . The following conclusions were drawn:

(1) It is not possible from an initial improvement to obtain an idea of the later prognosis.

(2) Judging from our material, the male has a distinctly more favourable prognosis.

Of the males, 28 per cent. were "symptom-free", 31 per cent. " improved ", 15 per cent. " unchanged ", and 26. per cent. "deteriorated".

Of the females only 9 per cent. were "symptom-free", 30 per cent. " improved", 17 per cent. " unchanged ", and as many as 44 per cent. " deteriorated".

The symptom-free group comprised 15 per cent. of all cases, this figure agreeing well with results obtained by other investigators, whose figures as a rule lie between 10 and 15 per cent. A further 30 per cent. of the total were improved. Thus, the symptom-free and improved groups together represent 45 per cent. of the whole number, and 38 per cent. were found to have deteriorated.

(3) Patients who contract the disease at an early age have a better prognosis than those who acquire it at a later age.

(4) It appears important that gold therapy should be introduced at an early stage. Cases in which the gold treatment was begun a year after the start of the disease showed much better results than those in which it was begun later. 
REFERENCES

Egelius, N., Hävermark, N. G., and Jonsson, E. (1949). Annals of the Rheumatic Diseases, 8, 217. $\longrightarrow$ and Nyström, G. (1951). Nord. Med., 45, 968.

Ellman, P., Lawrence, J. S., and Thorold, G. P. (1940). Brit. med. J., 2, 314.

Fraser, T. N. (1945). Annals of the Rheumatic Diseases, 4, 71.

Freyberg, R. H. (1942). Proc. Mayo Clin., 17, 534.

Kling, D. H., Vento, J. P., and Sashin, D. (1949). Rheumatism, 5, 93.

Ragan, C., and Tyson, T. L. (1946). Amer. J. Med., 1, 252.

Secher, K. (1944-46). ' "Directions for the Treatment of Rheumatic Joint Disease. Bispebjerg Hospital.' Short, C. L., Beckman, W. W., and Bauer, W. (1946). New Eng. J. Med., 235, 362.

Snorrason, E. (1950). “ Polyarthritis chronica primaria. Sanocrysinbehandling og Prognose.” Richter, Copenhagen,

Steinbrocker, O., and Blazer, A. (1946). New Eng. J. Med., 235, 501.

-, Traeger, C., and Batterman, R. (1949). J. Amer. med. Ass., 140, 659.

Waine, H., Baker, F., and Mettier, S. R. (1947). Calif. Med., 66, 295.

\section{Résultats éloignés du traitement de l'arthrite rhumatismale par des sels d'or \\ RÉSUMÉ}

On a examiné des malades (dont deux tiers étaient des femmes) atteints d'arthrite rhumatismale 5 à 15 ans après le traitement par des sels d'or. On arriva à des conclusions suivantes:

(1) Une amélioration initiale n'offre aucune indication pronostique ultérieure.

(2) D'après le matériel étudié, le pronostic chez les hommes est nettement plus favorable. Parmi les hommes, 28\% étaient "sans symptômes", 31\% " améliores ", 15\% " sans changement", et $26 \%$ "empirés".

Parmi les femmes, 9\% seulement étaient " sans symptômes ", 30\% “ améliorées ", 17\% " sans changement", et jusqu'à $44 \%$ "empirées".

Le groupe de "sans symptômes" représentait 15\% du chiffre total, ce qui concorde avec les résultats des autres auteurs, dont les chiffres, en général, varient entre 10 et 15 pour cent. Avec un pourcentage total de $30 \%$ d' " améliorés", on arrive à $45 \%$ des résultats favorables. Dans $38 \%$ des cas la santé des malades s'était aggravé.

(3) Le pronostique de ceux qui contractent la maladie à un âge préccoe set meilleur que celui des rhumatisants au début tardif.

(4) Il parait important qu'on commence le traitement par des sels d'or de bonne heure. Des cas où ce traitement avait commencé un an après le début de la maladie présentent de meilleurs résultats que ceux traités plus tard.

\section{Resultados tardíos de la auroterapia de la artritis reumatoide}

\section{SUMARIO}

Enfermos con artritis reumatoide (dos terceras del sexo femenino) fueron examinados de cinco a quince años después del tratamiento con sales de oro. Se llegó a las conclusiones siguientes:

(1) Una mejoría inicial no ofrece indicación alguna respecto al pronóstico ulterior.

(2) Basándose en el material entero, el pronóstico para los hombres es netamente más favorable.

El $28 \%$ de los hombres estaban "sin síntomas", el $31 \%$ " mejorados", el $15 \%$ " sin cambiar", y el 26\% "empeorados".

Respectó a las mujeres, el 9\% sólo estaban " sin síntomas", el 30\% " mejoradas", el 17\% " sin cambiar", y hasta el $44 \%$ " empeoradas".

El grupo de " sin síntomas" comprendía el 15\% del total de los casos, lo que corresponde a los resultados obtenidos por otros investigadores, cuyas cifras oscilan generalmente entre el 10 y el 15 por ciento. El 30\% del total pertenecía al grupo de los "mejorados", que con el previo grupo forman el $45 \%$ de resultados favorables. El 38\% del total había empeorado.

(4) Enfermos que contraen la enfermedad a una edad temprana tienen el pronóstico mejor que los demás.

(5) El tratamiento precoz con sales de oro parece ser importante; en casos en que éste fué empezado un año después del principio de la enfermedad se obtuvo mejores resultados que en los en que fué instituido más tarde. 